\title{
Ice sheet model dependency of the simulated Greenland Ice Sheet in the mid-Pliocene
}

\author{
S. J. Koenig ${ }^{1}$, A. M. Dolan ${ }^{2}$, B. de Boer ${ }^{3,4}$, E. J. Stone ${ }^{5}$, D. J. Hill ${ }^{2,6}$, R. M. DeConto ${ }^{1}$, A. Abe-Ouchi ${ }^{7,8}$, D. J. Lunt ${ }^{5}$, \\ D. Pollard ${ }^{9}$, A. Quiquet ${ }^{10, *}$, F. Saito ${ }^{8}$, J. Savage ${ }^{5}$, and R. van de Wal $^{4}$ \\ ${ }^{1}$ Department of Geosciences, University of Massachusetts, 611 N. Pleasant St, Amherst, MA 01003, USA \\ ${ }^{2}$ School of Earth and Environment, Earth and Environment Building, University of Leeds, Leeds, LS2 9JT, UK \\ ${ }^{3}$ Department of Earth Sciences, Faculty of Geosciences, Utrecht University, Budapestlaan 4, \\ 3584 CD Utrecht, the Netherlands \\ ${ }^{4}$ Institute for Marine and Atmospheric Research, Utrecht (IMAU), Utrecht University, P.O. Box 80005, \\ 3508 TA Utrecht, the Netherlands \\ ${ }^{5}$ School of Geographical Sciences, University of Bristol, University Road, Bristol, BS8 1SS, UK \\ ${ }^{6}$ British Geological Survey, Keyworth, Nottingham, UK \\ ${ }^{7}$ Atmosphere and Ocean Research Institute, The University of Tokyo, Kashiwa 277-8568, Japan \\ ${ }^{8}$ Japan Agency for Marine-Earth Science and Technology, Yokohoma 236-001, Japan \\ ${ }^{9}$ Earth and Environmental Systems Institute, Pennsylvania State University, University Park, PA 16802, USA \\ ${ }^{10} \mathrm{UJF}$ - Grenoble 1/CNRS, Laboratoire de Glaciologie et Géophysique de l'Environnement (LGGE) \\ UMR5183, Grenoble, 38041, France \\ *now at: Department of Geography, University of Cambridge, Cambridge, CB2 3EN, UK
}

Correspondence to: S. J. Koenig (koenig@geo.umass.edu)

Received: 8 May 2014 - Published in Clim. Past Discuss.: 9 July 2014

Revised: 30 October 2014 - Accepted: 18 November 2014 - Published: 5 March 2015

\begin{abstract}
The understanding of the nature and behavior of ice sheets in past warm periods is important for constraining the potential impacts of future climate change. The Pliocene warm period (between 3.264 and $3.025 \mathrm{Ma}$ ) saw global temperatures similar to those projected for future climates; nevertheless, Pliocene ice locations and extents are still poorly constrained. We present results from the efforts to simulate mid-Pliocene Greenland Ice Sheets by means of the international Pliocene Ice Sheet Modeling Intercomparison Project (PLISMIP). We compare the performance of existing numerical ice sheet models in simulating modern control and mid-Pliocene ice sheets with a suite of sensitivity experiments guided by available proxy records. We quantify equilibrated ice sheet volume on Greenland, identifying a potential range in sea level contributions from warm Pliocene scenarios. A series of statistical measures are performed to quantify the confidence of simulations with focus on intermodel and inter-scenario differences. We find that Pliocene
\end{abstract}

Greenland Ice Sheets are less sensitive to differences in ice sheet model configurations and internal physical quantities than to changes in imposed climate forcing. We conclude that Pliocene ice was most likely to be limited to the highest elevations in eastern and southern Greenland as simulated with the highest confidence and by synthesizing available regional proxies; however, the extent of those ice caps needs to be further constrained by using a range of general circulation model (GCM) climate forcings.

\section{Introduction}

One of the largest uncertainties in predicting future climate change is associated with the response of the ice sheets. Instrumental records in the vicinity of the Greenland Ice Sheet (GrIS) show anomalous changes in surface temperatures from pre-industrial to modern (Box, 2002). These, along with 
recent satellite data and surface mass balance calculations (Box et al., 2004; Mote, 2007; Rignot et al., 2008; Bhattacharya et al., 2009; van den Broeke et al., 2009; Mernild et al., 2011; Rignot et al., 2011; Shepherd et al., 2012), indicate that high-latitude ice sheet climate environments are particularly sensitive to change and to anthropogenic warming in particular.

Continental ice sheets can respond to imposed forcings on up to multi-millennial timescales, which limits the ability of predicting cryospheric stability based solely on interannual to decadal variability from instrumental records. Recent modeling studies have focused on the long-term response of the GrIS to elevated greenhouse gas levels. Simulations show that under potential anthropogenic warming scenarios, the GrIS will disintegrate within a few thousand years (Berger, 2002; Gregory et al., 2004; Ridley et al., 2005; Vizcaíno et al, 2008; Stone et al., 2010; Huybrechts et al., 2011b; Robinson et al., 2012). Moreover, a hierarchy of models predict significant reductions of grounded ice on Greenland, even if levels are stabilized at modern levels (Loutre, 1995; Huybrechts and de Wolde, 1999; Greve, 2000; Gregory et al., 2004). A direct consequence of complete disintegration will be a global-average sea level rise of about $7 \mathrm{~m}$, as inferred from present-day volumetric calculations (Bamber and Aspinall, 2013) and modeling work (Alley et al., 2005). The potential loss of the ice sheet raises questions regarding the strength of ice sheet hysteresis (see Calov and Ganopolski, 2005; Pollard and DeConto, 2005; Fyke et al., 2011; Robinson et al., 2012; Koenig et al., 2014) and the possibility that the ice sheet will not reform (regrowth potential) once it is lost (Crowley and Baum, 1995; Lunt et al., 2004; Toniazzo et al., 2004; Ridley et al., 2010; Dowsett et al., 2012; Stone and Lunt, 2013). Studies of palaeo-variations of GrIS can contribute to the understanding of these issues and the envelope of its behavior in future warmer climate scenarios.

Palaeoclimatic studies of proxy records (NEEM Community Members, 2013) and numerical modeling (Cuffey and Marshall, 2000; Otto-Bliesner et al., 2006; van de Berg et al., 2011; Colville et al., 2011; Helsen et al., 2013; Reyes et al., 2014) of the past few interglacials confirm that GrIS has a large sensitivity to high-latitude warming. The midPiacenzian (Dowsett et al., 2010a) or Pliocene warm period (between 3.264 and $3.025 \mathrm{Ma}$ ) has been identified as a potential past climate of high commonality to projected future warming (Haywood et al., 2011a), with higher than modern surface temperatures and with boundary conditions and forcings similar to today (e.g., Pagani et al., 2009; Seki et al., 2010). Hence, the Pliocene warm period (henceforth referred to as the Pliocene) is a particularly suitable period to test the sensitivity of the ice sheet in an environment relevant to future global change.

Terrestrial and marine records for the Pliocene exist in the vicinity of Greenland and act as recorders of environmental change for the warmest interglacials and episodes of glaciation during the Pliocene (De Schepper et al., 2014 for an overview). Ice-rafted debris events recorded in nearby sediments in the North Atlantic are indicative of grounded ice on Greenland. Only a few episodic events occur in the early to mid-Pliocene and become more abundant in the late Pliocene to early Pleistocene (Larsen et al., 1994; Wolf-Welling et al., 1996; Jansen et al., 2000; Kleiven et al., 2002; John and Krissek, 2002; Alley et al., 2010). This is consistent with sea surface temperatures and $\delta^{18} \mathrm{O}$ reconstructions in the vicinity of Greenland, which suggest that highly variable and reduced Greenland ice cover prevailed in the late Pliocene before more stable and extensive ice sheets were attained in the early Pleistocene (Nielsen and Kuijpers, 1991; Lawrence et al., 2009).

There is considerable disagreement between sea-level high-stand reconstructions for the Pliocene, with estimates from proxy records and isostatic modeling ranging from $5 \mathrm{~m}$ to $44 \mathrm{~m}$ above modern sea level (e.g., Dowsett et al., 2010a; Siddall et al., 2010 and references therein; Raymo et al., 2011; Raymo and Mitrovica, 2012). Stacks of benthic $\delta^{18} \mathrm{O}$ (Lisiecki and Raymo, 2005) provide a global measure of cryospheric variability; however, it is challenging to disentangle Greenland and Antarctic ice sheet fluctuations. Due to the light isotopic signature, in combination with the limited volume changes of the Greenland Ice Sheet the signal is hard to be inferred from the $\delta^{18} \mathrm{O}$ global stack.

More detailed aspects such as the locations of individual ice centers on Pliocene Greenland require climate and ice sheet modeling. A few modeling studies have attempted to simulate the Greenland Ice Sheet during the mid- to late Pliocene (Lunt et al., 2008, 2009; Hill, 2009; Dolan et al., 2011; Koenig et al., 2011; Solgaard et al., 2011; Koenig et al., 2014). However, assessment of these results has been hindered by the use of disparate initial and boundary conditions and prescribed external forcing.

Global data sets of proxy reconstructions for the Pliocene have recently been established (PRISM3D, Dowsett et al., 2010a, b) providing an excellent framework for modeling studies. A consistent data-driven modeling approach can help to compare models and the sensitivity of ice sheets in the Pliocene leading to a better understanding of long-term future ice sheet response.

This paper aims to reconstruct the location and amount of grounded ice on Pliocene Greenland by means of an ice sheet model intercomparison project (PLISMIP, Dolan et al., 2012). We apply a data-driven experimental design to provide a better understanding of the dynamics involved in Greenland's climatic and ice sheet variability. The specific objectives are to identify the uncertainties in sea level contribution due to ice sheet model differences, estimate the potential range in GrIS reconstructions of the Pliocene warm interval, and to quantify the impact of prescribing different ice sheet reconstructions in a climate model. A companion paper will follow, which, in combination with this study, will assess climate model dependency of ice sheet simulations over Greenland for the same time period (Dolan et al., 2015). 
Table 1. Experiments for PLISMIP follow Control and Pliocene Phases. Forcing climatologies are from HadAM3 GCM control and NCEP re-analysis data (see Sect. 2.1). ISM simulations are initiated with modern, PRISM3 ice sheet configurations (Hill, 2009) and icefree conditions with respective topographies. The ice-free scenarios use isostatically rebounded topography on Greenland.

\begin{tabular}{llll}
\hline Run ID & $\begin{array}{l}\text { Driving } \\
\text { Climatology }\end{array}$ & $\begin{array}{l}\text { ISM } \\
\text { Configurations }\end{array}$ & Phase \\
\hline $\begin{array}{l}\text { Control } \\
\text { Control }\end{array}$ & $\mathrm{Had}_{\text {ctrl }}$ & $\begin{array}{l}\text { Modern } \\
\text { Modern }\end{array}$ & Control \\
$\mathrm{NCEP}_{\text {ctrl }}$ & Plio & \\
Plio $_{\text {prism.icefree }}$ & $\mathrm{Had}_{\text {prism }}$ & Ice-free & Pliocene \\
Plio $_{\text {nogris.icefree }}$ & $\mathrm{Had}_{\text {prism }}$ & PRISM3 & \\
\hline
\end{tabular}

\section{Methods}

A set of forcing climatologies and initial conditions are applied to simulate Greenland's mass balance in the Pliocene relative to pre-industrial/modern. We first describe the experimental design, followed by model-specific details in Sect. 2.1.2.

\subsection{Experimental design}

Dolan et al. (2012) provide an overview of PLiocene Ice Sheet Modeling Intercomparison Project (PLISMIP) and describes its experimental design, but important details will be reiterated here for convenience. The Control Phase of this project aims at testing individual ice sheet model performances under present-day forcings, whereas the Pliocene Phase is designed to span an envelope of potential Pliocene scenarios by applying a range of climate forcings, and ice sheet model starting conditions on Greenland (Table 1, Fig. 1).

\subsubsection{Forcing}

In the first set of experiments (Control Phase), the ice sheet models (ISMs) are initialized with model-specific presentday ice sheets, and driven by climatologies either from a HadAM3 pre-industrial control run or from the independent NCEP/DOE AMIP-II re-analysis data set (hereafter NCEP2, Kanamitsu et al., 2002). These tests identify modeldependent biases when simulating present-day (or equivalent) Greenland Ice Sheets using a single general circulation model (GCM) relevant for the inter-model interpretation of palaeo-experiments.

Two HadAM3 GCM climatologies are used to drive ISM simulations of Pliocene Greenland (Pliocene Phase, Fig. 1). The first climatology is from the main PlioMIP HadAM3 experiment using PRISM3 Pliocene boundary conditions ( Had $_{\text {prism, }}$, see Dowsett et al., 2010a; Haywood et al., 2010). The second climatology is from another HadAM3 GCM sen- sitivity experiment using the same PRISM3 boundary conditions except for isostatically adjusted ice-free Greenland topography ( Had $_{\text {plio.nogris }}$ ). The latter scenario is added to quantify the uncertainties in simulating the maximum sea level contributions by imposing a significant ice mass in the Pliocene climatology used to force the ice sheet models. The initial Greenland Ice Sheet state for the ISM simulations is either that provided by Hill (2009) (PRISM3 GrIS, see Dolan et al., 2011) or ISM-specific ice-free rebounded topographies.

There are various methods that account for temporal and spatial mismatches in scale between GCMs and ice sheet models (see Pollard, 2010 for an overview). Here, we avoid problems associated with the temporal mismatch by considering the equilibrated ice sheet response to a given climate, rather than the transient behavior, i.e., Control and Pliocene GCM climatologies are used to drive individual ISMs to an equilibrated response. The spatial mismatch is accounted for as described below.

Monthly and annual mean temperatures and precipitation fields from the GCM and re-analysis data set are re-gridded to the required ISM resolution using the interpolation method specific to each ISM (see Sect. 2.1.2 and references therein). To account for the high-resolution ISM orography compared to the coarser GCM and re-analysis grids, a uniform lapse rate correction is applied with a value of $8^{\circ} \mathrm{C} \mathrm{km}^{-1}$ (Thompson and Pollard, 1997). First, the GCM/re-analysis topography and surface air temperatures are horizontally interpolated to the ISM grid, and then the temperature is corrected vertically to the ISM surface by $T-\gamma \times\left(Z_{\mathrm{ISM}}-Z_{\mathrm{GCM}}\right)$, where $T$ is the GCM/re-analysis surface air temperature, $Z_{\mathrm{ISM}}$ elevation of the ice sheet model, $Z_{\mathrm{GCM}}$ is the $\mathrm{GCM} / \mathrm{re}$ analysis surface elevation, and $\gamma$ is the lapse rate. Each ISM simulation is run for $30 \mathrm{kyr}$, and extended to equilibrium if necessary in $10 \mathrm{kyr}$ increments until the relative change in total ice volume per 1000 years falls below $0.01 \%$.

\subsubsection{Ice sheet models}

Table 3 provides an overview of ice sheet models applied in the experiments. The specifics of each ice sheet model that are relevant for the PLISMIP experiments, i.e., ISM resolution, mass balance calculation, geothermal heat flux, bedrock response model, and further model details are available in the respective references (ANICE, de Boer et al., 2013; BASISM, Hill, 2009; Dolan et al., 2011; Glimmer, Rutt et al., 2009; GRISLI, Ritz and Rommelaere, 2001; Peyaud et al., 2007; IcIES, Saito, 2002; Saito and Abe-Ouchi, 2004; PSUI, Pollard and DeConto, 2007, 2012). Apart from Glimmer, all ISMs are run in absolute mode, i.e., forced with absolute climatologies rather than using an anomaly method that combines climatological anomalies with a control climate (see, e.g., Lunt et al., 2008). 

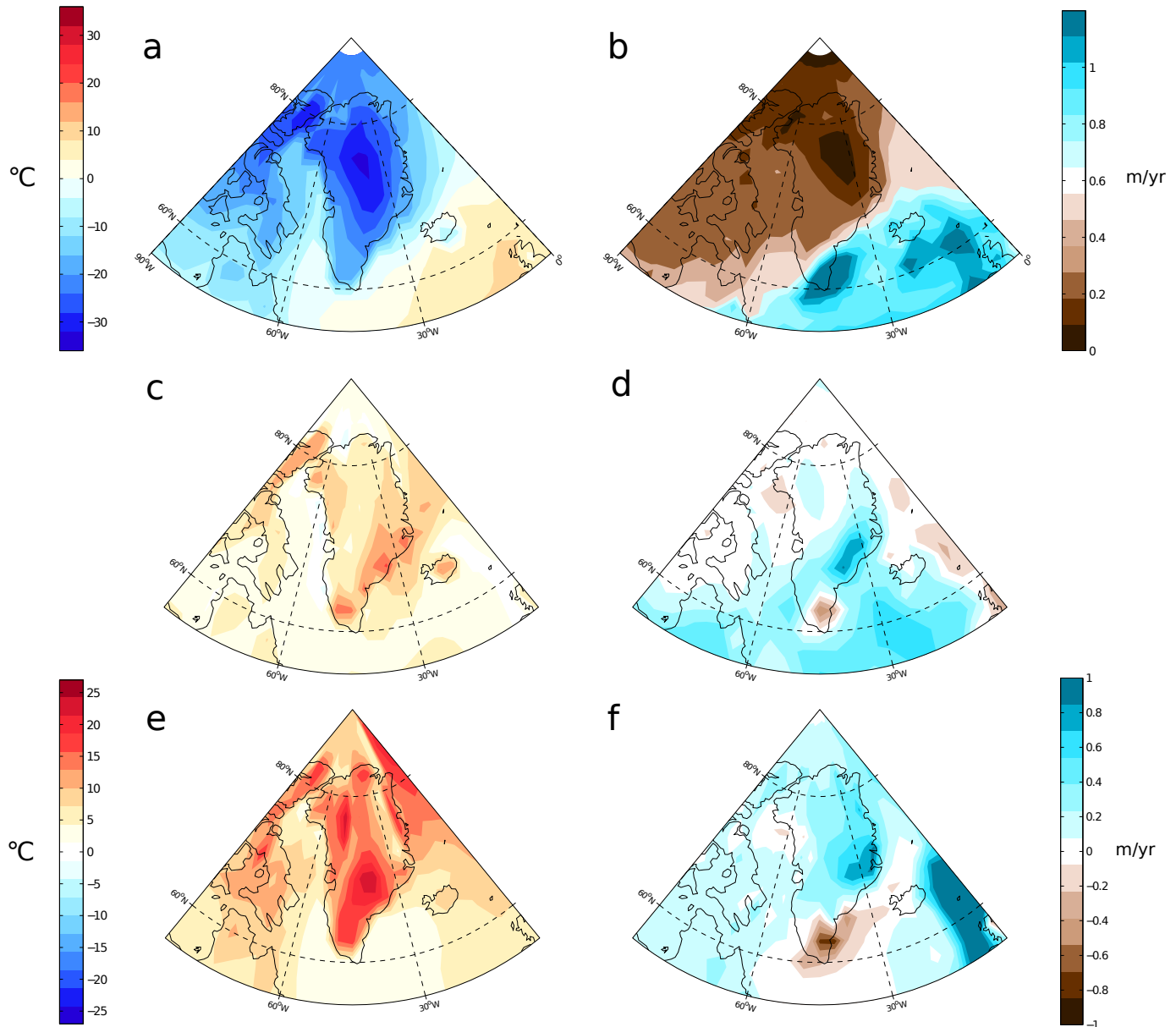

f
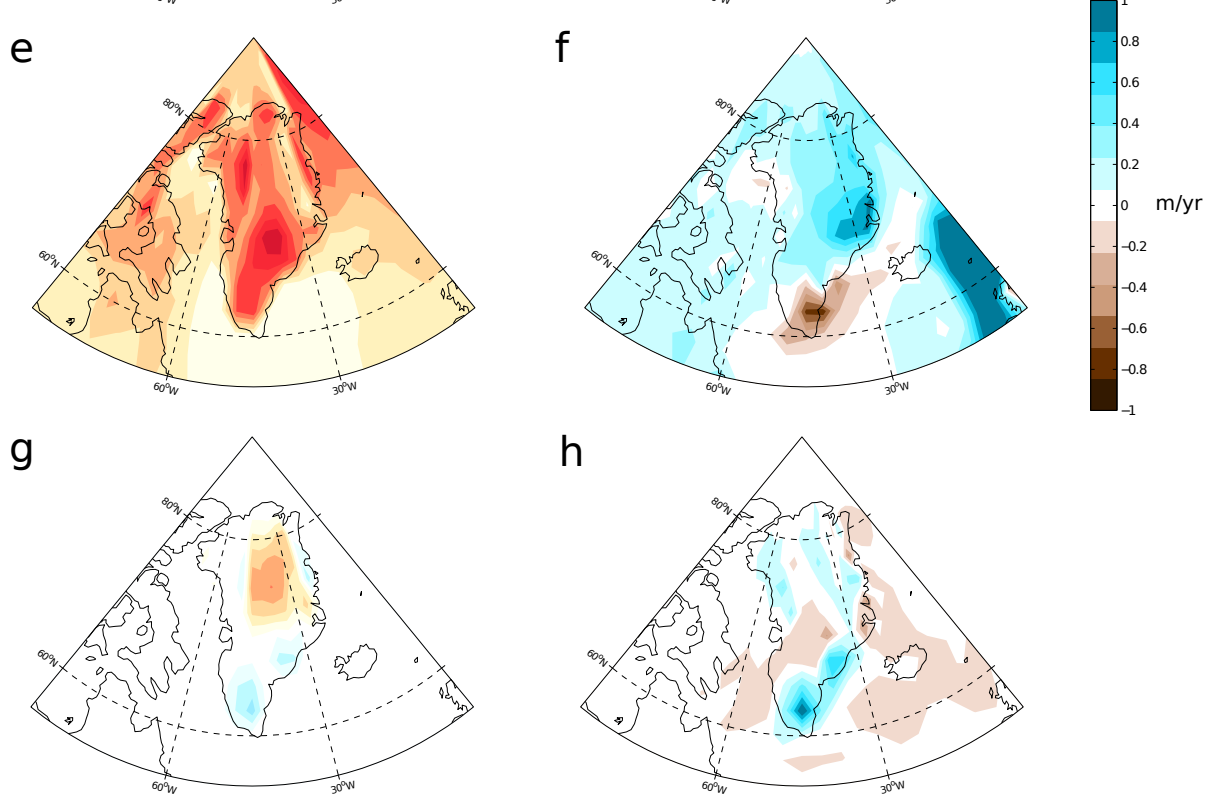

Figure 1. Control and Pliocene Phase driving climatologies. Annual surface temperatures $\left[{ }^{\circ} \mathrm{C}\right]$ and precipitation $\left[\mathrm{m} \mathrm{yr}^{-1}\right]$ for $(\mathbf{a}-\mathbf{b}) \mathrm{Had}_{\mathrm{ctrl}}$, (c-d) $\mathrm{NCEP} 2_{\text {ctrl }}-\mathrm{Had}_{\mathrm{ctrl}}$ differences, $(\mathbf{e}-\mathbf{f}) \mathrm{Had}_{\text {prism }}-\mathrm{Had}_{\mathrm{ctrl}}$ differences, and $(\mathbf{g}-\mathbf{h})$ Had $\mathrm{d}_{\text {plio.nogris }}-\mathrm{Had}_{\text {prism }}$ differences. Note change in scales for absolute (a-b) and difference calculations (c-h).

\section{Results}

Initially we test the performance of ice sheet models in simulating present-day (or pre-industrial) ice sheets forced with GCM and re-analysis data, respectively (Sects. 3.1, 3.2). We analyze Pliocene scenarios both spatially and temporally (Sect. 3.3.1) before quantifying the variability (i) among ice sheet models and (ii) between climate scenarios through sets of statistical measures (Sect. 3.3.2).

\subsection{Ice sheet model forcing}

Absolute mean annual surface temperatures in modern control simulations from the HadAM3 GCM $\left(\mathrm{Had}_{\mathrm{ctrl}}\right)$ are below freezing over all of Greenland with minimum values of $-28^{\circ} \mathrm{C}$ centered over the highest altitudes (Fig. 1a). Precipitation follows the spatial pattern of temperature with relatively low values over much of Greenland except in regions of southern Greenland where moisture transport from the North Atlantic increases precipitation to $>1 \mathrm{~m} \mathrm{yr}^{-1}$ (Fig. 1b). In comparison, annual surface temperatures and 
precipitation values from NCEP2 re-analysis $\left(\mathrm{NCEP} 2_{\text {ctrl }}\right)$ are warmer by $5-7^{\circ} \mathrm{C}$ and slightly wetter (Fig. 1c-d). For the Pliocene Phase, both driving climates $\left(\operatorname{Had}_{\text {prism }}\right.$, Had $_{\text {plio.nogris }}$ ) show temperature anomalies with respect to modern of $+15^{\circ} \mathrm{C}$ up to $+23^{\circ} \mathrm{C}$ in regions where ice sheet reconstructions between Pliocene and modern deviate and elevation and ice-albedo feedbacks are maximized (see Dolan et al., 2012) (Fig. 1e). An additional increase in surface temperatures of $5-8^{\circ} \mathrm{C}$ is simulated in response to ice-free conditions in the Pliocene GCM scenario Had plio.nogris $_{\text {when }}$ compared to the Pliocene scenario $\mathrm{Had}_{\text {prism. Slightly higher }}$ elevations of the ice-free rebounded topography result in wetter $\left(0.6-1 \mathrm{~m} \mathrm{yr}^{-1}\right)$ and slightly colder surface temperatures $\left(\sim 1-2{ }^{\circ} \mathrm{C}\right)$ in southern Greenland (Fig. 1g-h).

\subsection{Modern control Greenland Ice Sheet}

Bamber et al. (2001a) used airborne laser altimeter data and cartographic data sets to reconstruct a digital elevation data set for Greenland. Ice thickness data is combined with the digital elevation model of Bamber et al. (2001b) resulting in an estimated volume of $2.931 \times 10^{6} \mathrm{~km}^{3}$ for the present-day ice sheet. Calculations using Bamber et al. (2001b) data estimate the area to $1.67 \times 10^{6} \mathrm{~km}^{2}$ (unpublished work, Byrd Polar Research Center). Equilibrated ice sheet model simulations using control GCM $\left(\operatorname{Had}_{\text {ctrl }}\right)$ and $\mathrm{NCEP} 2_{\text {ctrl }}$ forcings compare favorably with volumetric and areal estimates for modern GrIS (Table 2, Control ${ }_{\text {ncep }}$, not shown). Here we assume that ISMs forced with a pre-industrial simulation will reproduce an ice sheet configuration comparable to the present day. The total of all ISMs averages to $3.42 \pm 0.47 \times$ $10^{6} \mathrm{~km}^{3}$ for volume and to $2.03 \pm 0.26 \times 10^{6} \mathrm{~km}^{2}$ for areal ice sheet extent, overestimating volume by $18 \%$, and area by $21 \%$. When forced with the HadAM 3 climate, Glimmer produces an ice sheet which extends into the modern ocean in the southeast, resulting in a large ice area. The GRISLI ISM significantly overestimates volume, which has consequences for the multi-model average (Table 2).

Figure 2 shows grid-cell elevation differences between simulated control scenarios (Control ${ }_{h a d}$, Control $_{\text {ncep }}$ ) and modern-day observed ice sheets from Bamber et al. (2001a). Both control scenarios lead to comparable present-day ice volumes and extents relative to observations. In addition, modeled ice sheets forced by the GCM climatology $\mathrm{Had}_{\mathrm{ctrl}}$ do not significantly differ from the ones forced by re-analysis data $\left(\mathrm{NCEP} 2_{\mathrm{ctrl}}\right)$. The majority of ISMs simulate presentday GrIS with overall lower elevations $(<250 \mathrm{~m})$ in the center when compared to measurements (with the exception of GRISLI). Ice margins are generally overestimated accounting for the deviations in Table 2. Elevation changes in southwestern, eastern, and northeastern Greenland amount to $>1000 \mathrm{~m}$ at the ice margins, a feature uniformly seen in almost all ISMs.

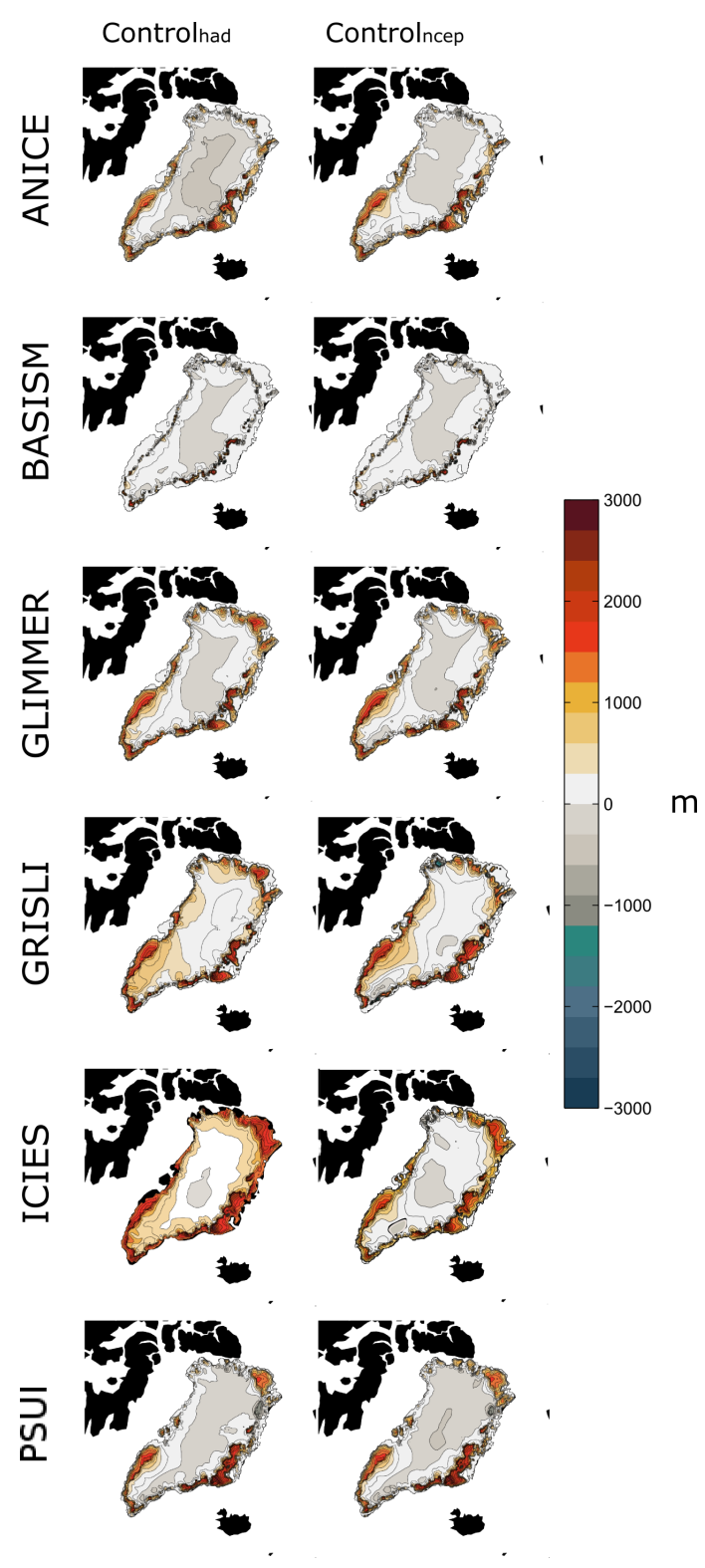

Figure 2. Ice sheet surface elevation [m] anomalies for Control had (left panels) and Controlncep (right panels) relative to observed present-day Greenland Ice Sheet calculations from Bamber et al. (2001a) for individual ice sheet models ANICE, BASISM, Glimmer, GRISLI, IcIES, and PSUI (from top to bottom). Modern-day coastlines are used, and the ocean is masked out for plotting the anomalies.

\subsection{Pliocene Greenland Ice Sheet}

\subsubsection{Evolution and equilibrated ice sheets}

In Fig. 3 the temporal evolution of modeled ice volume is expressed as sea level equivalent meters for runs Plioprism.icefree, $_{\text {Plio }}$ prism, and Plio ${ }_{\text {nogris.icefree. Equilibrium is }}$ effectively reached for most of the runs and scenarios at year 

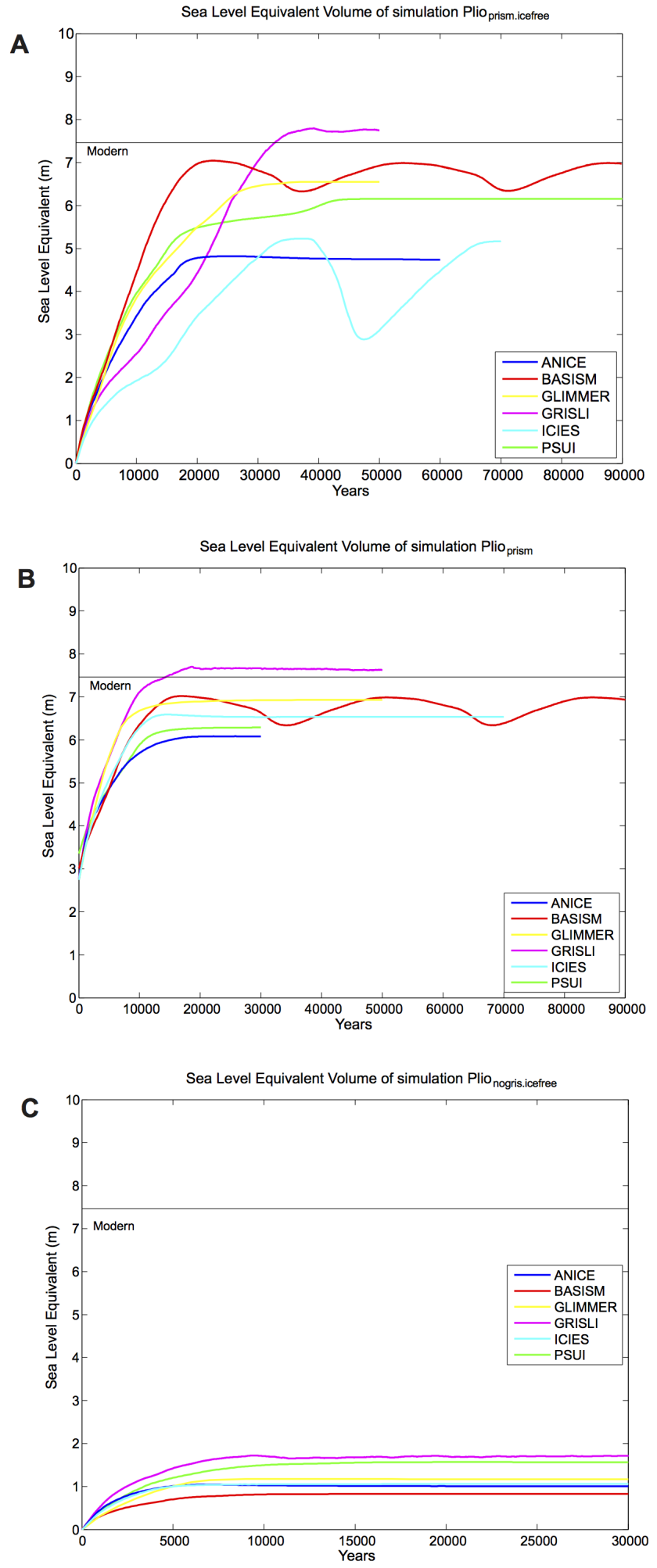

Figure 3. Evolution of ice sheet volumes expressed in sea level equivalent meters [m] for Pliocene scenarios (a) Plio prism.icefree,

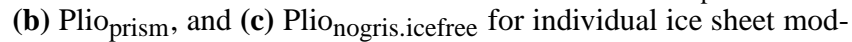
els. Observed present-day values from Bamber et al. (2001a) are indicated for reference. Note changes in integration lengths for scenarios ( $x$ axis).

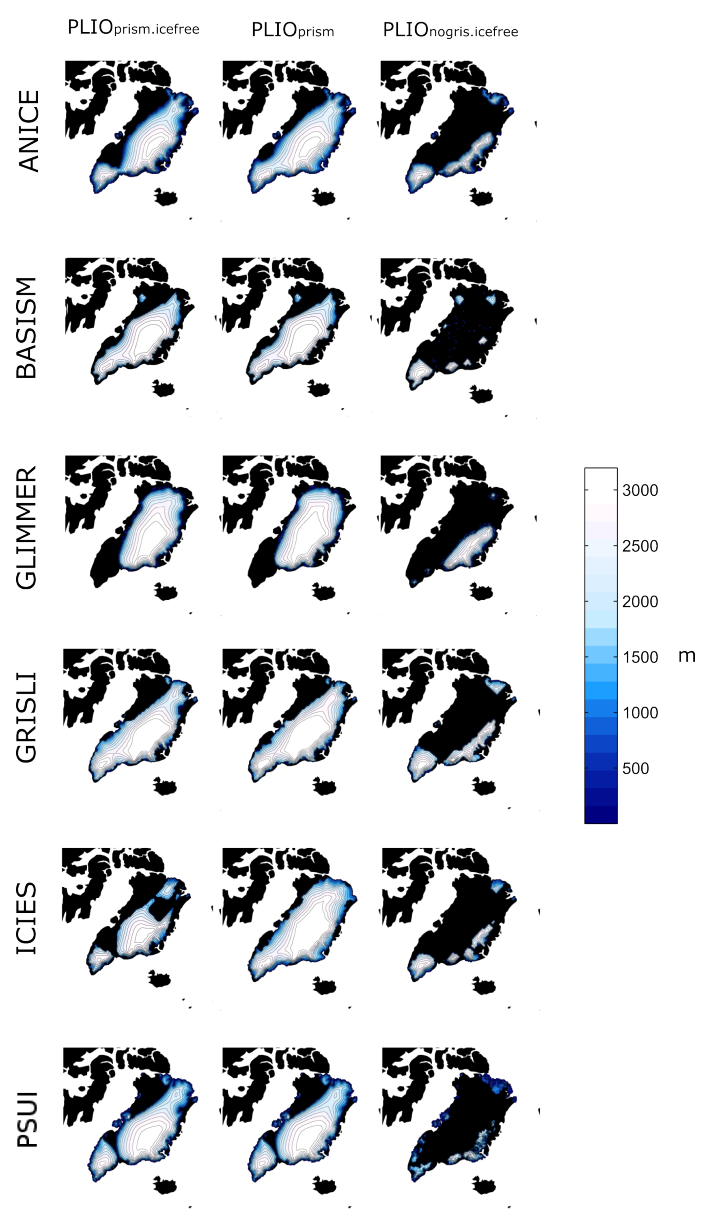

Figure 4. Ice sheet surface elevation $[\mathrm{m}]$ for Pliocene scenar-

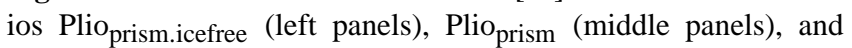
Plio nogris.icefree (right panels) for individual ice sheet models ANICE, BASISM, Glimmer, GRISLI, IcIES, and PSUI (from top to bottom).

$30 k$ (see Sect. 2.1) although ISMs require a longer integration time to equilibrate to the Plio prism.icefree scenario due to larger deviations between forcing climatology and initial ice sheet model configuration on Greenland. Ice volumes for BASISM scenarios Plio prism.icefree and Plio $_{\text {prism }}$ and IcIES

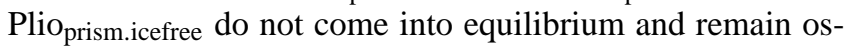
cillating between a stable maximum and minimum due to bedrock and ice interactions. In these instances, the median volume of a full cycle near the end of the run is selected as representative of ISMs' end state. Except the reconstructions from GRISLI, all Pliocene scenarios lead to volumes that are below modern estimates. The range of modeled volumes from Plio prism.icefree and Plio prism are within sea level equivalent meters of $4.2-7.6 \mathrm{~m}$ and stand in contrast to the scenario Plionogris.icefree with values between 0.8 and $1.7 \mathrm{~m}$.

Although Pliocene simulations result in equilibrated ice sheets significantly smaller in comparison to modern, ice sheet location, extent, and volumes differ considerably be- 
Table 2. Equilibrated ice sheet volume $\left[\mathrm{km}^{3} \times 10^{6}\right]$ and area $\left[\mathrm{km}^{2} \times 10^{6}\right]$ for Control Phase scenario Control had $_{\text {for individual ice sheet }}$ models. ISMs all denotes all-model means.

\begin{tabular}{lrrrrrrrr}
\hline & Observations* & ANICE & BASISM & Glimmer & GRISLI & IcIES & PSUI & ISMs all \\
\hline Volume & $2.93 \pm 0.13$ & 3.14 & 3.10 & 3.67 & 4.14 & 3.67 & 3.04 & $3.42 \pm 0.47$ \\
Area & $1.67 \pm 0.05$ & 2.08 & 1.66 & 2.22 & 2.01 & 2.15 & 2.07 & $2.04 \pm 0.26$ \\
\hline
\end{tabular}

* Volume and areal extent from Bamber et al. (2001a), standard deviation based on additional estimates by Ohmura (1991), Weng (1995),

Ohmura et al. (1999), Bindoff et al. (2007), Lemke et al. (2007), and Bamber and Aspinall (2013).

Table 3. Ice sheet model description table showing the resolution used in PLISMIP experiments, the mass balance method, whether there is basal sliding in the model, and how the model uses the climatological forcing. All models apply the climatological forcing with absolute values of temperatures $(T)$ and precipitation (PP), except Glimmer, and are run on a resolution of $20 \times 20 \mathrm{~km}$. SIA is shallow ice approximation, SSA is shallow shelf approximation, PDD is positive degree-day scheme, fd is finite difference.

\begin{tabular}{|c|c|c|c|c|c|}
\hline & Model Description & Mass Balance & Basal Sliding & Climate Forcing & References \\
\hline ANICE & $\begin{array}{l}\text { 3-D thermodynamic, } \\
\text { fd SIA explicit time-step }\end{array}$ & $T$ and radiation & Yes & $T$ and PP & de Boer et al. (2013) \\
\hline BASISM & $\begin{array}{l}\text { 3-D thermo-mechanic, } \\
\text { fd SIA semi-implicit }\end{array}$ & PDD & None & $T$ and $\mathrm{PP}$ & $\begin{array}{l}\text { Hindmarsh et al. (2001) } \\
\text { Hill (2009) }\end{array}$ \\
\hline Glimmer & $\begin{array}{l}\text { 3-D thermo-mechanic, } \\
\text { fd SIA semi-implicit }\end{array}$ & PDD & None & $T$ and $\mathrm{PP}$ & Rutt et al. (2009) \\
\hline GRISLI & $\begin{array}{l}\text { 3-D thermo-mechanic } \\
\text { Hybrid SIA/SSA semi-implicit }\end{array}$ & PDD & Yes & $T$ and PP & $\begin{array}{l}\text { Ritz and Rommelaere (2001) } \\
\text { Peyaud et al. (2007) }\end{array}$ \\
\hline IcIES & $\begin{array}{l}\text { 3-D thermo-mechanic } \\
\text { SIA semi-implicit }\end{array}$ & PDD & Yes & $T$ and PP & $\begin{array}{l}\text { Saito (2002) } \\
\text { Saito and Abe-Ouchi (2004) }\end{array}$ \\
\hline PSUI & $\begin{array}{l}\text { 3-D depth-averaged } \\
\text { Hybrid SIA/SSA alternating implicit }\end{array}$ & PDD & Yes & $T$ and $\mathrm{PP}$ & Pollard and DeConto $(2007,2012)$ \\
\hline
\end{tabular}

tween Pliocene forcing scenarios (Fig. 4). Both Pliocene ice sheet scenarios forced with GCM forcing using PRISM3 boundary conditions $\left(\mathrm{Had}_{\text {prism }}\right)$ are more extensive than the scenario forced with $\mathrm{Had}_{\text {nogris }}$. The latter forcing climatology has relatively higher surface temperatures over locations where ice reconstructions deviate (see Fig. 1). Forced with the same climatological means but different starting conditions, results from scenarios Plio ${ }_{\text {prism }}$ and Plioprism.icefree deviate by only $9 \%$ in volume and $9 \%$ in extent. However, the average volume or area for the Plionogris.icefree reconstructions correspond to a reduction of 19 and $36 \%$ relative to the latter two scenarios (see also Sect. 3.3.3).

\subsubsection{Inter-model and inter-scenario analysis}

Sample standard deviation (SSD) is a measure of the magnitude of a varying quantity. Here, it refers to the difference in the magnitude of simulated ice sheet thickness between the ice sheet models. SSD is calculated at each grid point by

$\mathrm{SSD}=\sqrt{\frac{x_{1}^{2}+x_{2}^{2}+\ldots+x_{\mathrm{n}}^{2}}{n-1}}$

where $x_{\mathrm{i}}$ is the difference between simulated ice sheet thickness in model (i) and the multi-model mean and $n$ is the number of models. Where SSD is low, the difference in simulated thicknesses between the ISMs is small and vice versa.
It can be interpreted as the differences in the dynamics of the ice sheet models in these regions (Fig. 5a-c). SSD values are $>1500 \mathrm{~m}$ in northeastern and southern-central Greenland in both PRISM3D scenarios Plio prism $_{1}$ and Plio prism.icefree, whereas the ice sheet dome region in eastern Greenland shows a low variability. Highest SSD values (> 2000) are calculated in southern regions for the Plionogris.icefree scenario. Other regions show generally low SSD values of $<800 \mathrm{~m}$ in variability.

When considered alongside the SSD plots, the ice sheet presence (Fig. 5d-f) suggests areas of Greenland that might be strongly affected by how each individual ISM calculates melting (see representation of ice dynamics). While higher values show regions where the majority of ISMs predict ice of any thickness, lower values indicate a reduced likelihood of ice presence for each particular scenario and correlates to regions of higher SSD values. Although in general ice sheet configurations are a balance between accumulation and melting, in these experiments the areal extent of the ice sheets is largely governed by how much melting is simulated in the ice sheet model; therefore, inconsistencies in ice area may be ascribed to differences in the ISMs melt schemes. There are differences in the details of the predictions between the

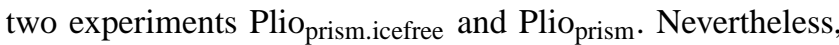
$100 \%$ of the models agree on the presence of large areas of ice over central and eastern Greenland, with $83 \%$ of the mod- 
A

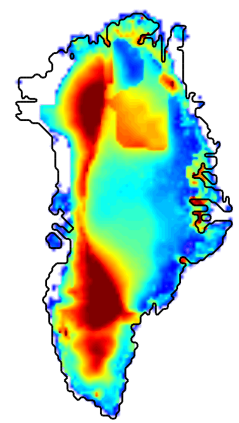

D

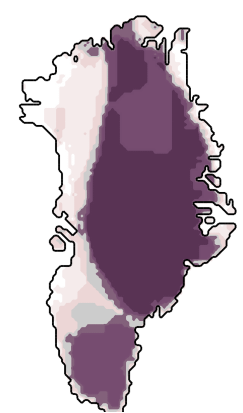

B

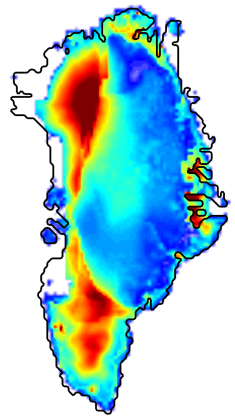

E

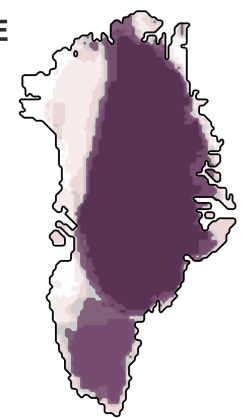

C

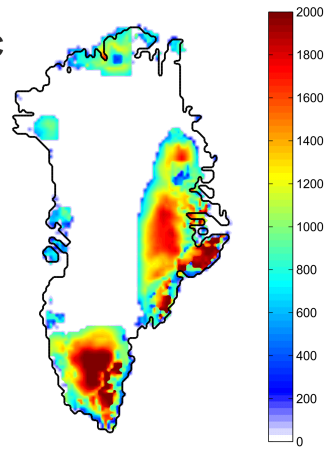

F

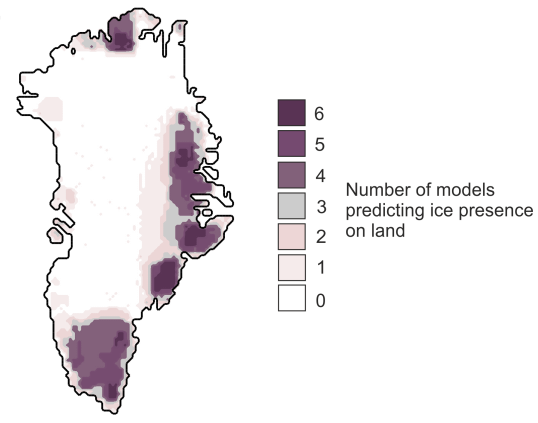

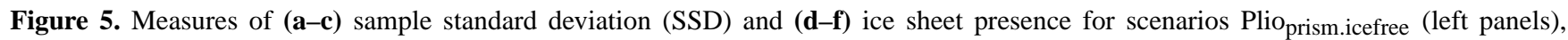

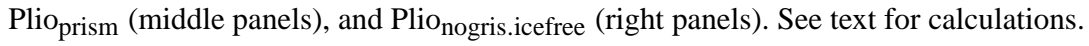

els predicting ice presence over areas in south Greenland. In

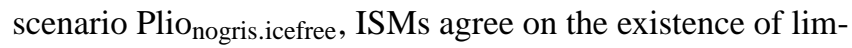
ited ice caps at eastern and southern high altitudes (100\%) and deviate by $20-40 \%$ of how extensive the ice sheets are in those areas.

Figure 6 synthesizes the results from the model intercomparison. For Fig. 6a we define $C$ as the confidence in reconstruction of ice presence at each grid point given a particular climatological forcing (inter-model confidence, where $k_{\mathrm{i}}$ is the number of models which have ice present in each scenario (i)). The total number of scenarios is defined by $j$, and $n$ is the total number of models (i.e., 6). Calculations are normalized to values $0-1$. For Fig. 6a, confidence is highest (1) when all models either agree on ice presence or absence in a particular grid square. Where half the models predict one result and the other half predict the opposite, confidence is low in the ice reconstruction $(C=0)$.

$C=\frac{2}{j \cdot n} \sum_{i=1}^{j}\left|k_{i}-\frac{n}{2}\right|$

High $C(>0.6-1)$ is obtained for an extensive area of Greenland with highest values in central and eastern regions of Greenland. Lower inter-model confidence is obtained in areas in southern Greenland with $C$ between 0.25 and 0.6. In addition, we calculate the overall likelihood of ice presence in a grid square during the Pliocene given the scenarios we have tested. We calculate the sum of ice presence through- out all of the Pliocene ISM simulations (normalized to $0-1$; Fig. 6b). In this case confidence is highest $(C=1)$ where all ISMs in each of the three Pliocene climate scenarios predict ice presence. We find the highest probability of ice presence in eastern high-altitude regions in agreement with high confidence $C$ simulated in those areas (see Fig. 6a). Ice is also reconstructed to be present in southern Greenland, although with slightly less agreement between ISMs.

\subsubsection{Relative sea level contributions in the Pliocene}

Pliocene ice sheet simulations are analyzed relative to modern observed areal extent, volume, and sea level equivalent height (Bamber et al., 2001a) in Fig. 7. In general, there is a correlation between relative changes in ice sheet volume and the equivalent change in areal extent. Relative changes of both Pliocene scenarios forced with GCM climatology $\left(\mathrm{Had}_{\text {prism }}\right)$ group generally feature low within-group variability, i.e., areally between 0.25 and $0.98 \times 10^{6} \mathrm{~km}^{2}$, and between 0.4 and $1.3 \times 10^{6} \mathrm{~km}^{3}$ in volume. Scenario Plioprism.icefree leads to slightly higher reductions in volume

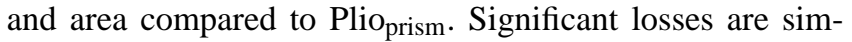
ulated for scenario Plionogris.icefree relative to modern, both areally and in terms of volume, corresponding to a sea level equivalent change of $\sim 6.1 \mathrm{~m}$ with respect to Bamber et al. (2001b) and when considering all ISMs. In summary, relative changes invoked by differing (ice sheet) boundary con- 


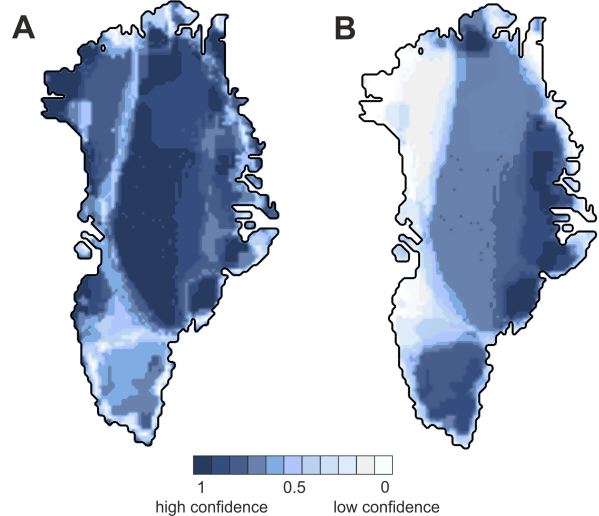

Figure 6. Measures of (a) inter-model and (b) overall confidence in Pliocene ice sheet simulations normalized to $0-1$. See text for calculations.

ditions in the GCMs are significantly larger than inter-model changes for a particular scenario.

\section{Discussion}

We test ice sheet model performances under present-day conditions before intercomparing simulations from palaeoscenarios (Sect. 3.2). We find that there are no systematic biases introduced when using HadAM3 GCM climatology relative to control experiments forced with NCEP2 re-analysis data. In general, ice sheet models compare favorably to observations, solely ice margins, and hence ice volume, are overestimated, a feature present in all ISMs. This can be attributed to problems in capturing the dynamic marginal ablation zones (see, e.g., Hindmarsh, 1993; Ritz et al., 1996). In turn, estimates of volume, extent, and sea level stemming from observations may not be in equilibrium with the present climate, adding to the observed discrepancies between simulated ice sheets and present-day estimates (Fig. 1).

The three ice sheet model scenarios for the Pliocene warm period presented here are designed to assess the envelope of ice sheet presence on Greenland. Scenarios Plio ${ }_{\text {prism }}$ and Plioprism.icefree lead to relatively extensive ice sheets due to a GCM forcing that mirrors prescribed ice sheets on Greenland (compare to original PRISM3 ice sheet reconstruction, Haywood et al., 2010). In turn, ISM results for scenario Plionogris.icefree equilibrate to ice caps that are limited to the nucleation centers at high elevations in eastern and southern Greenland as a result of higher surface temperatures of an ice-free topography. Proxy records of terrestrial and oceanic origin (see Sect. 1) reconstruct a Pliocene Greenland similar to a projected future Greenland with very limited ice cover (see, e.g., Ridley et al., 2005; Huybrechts et al., 2011a). Reconstructions of palaeo-vegetation for the Pliocene agree, in particular, on ice-free conditions in northern and northeastern Greenland, and regions in southern Greenland (e.g.,

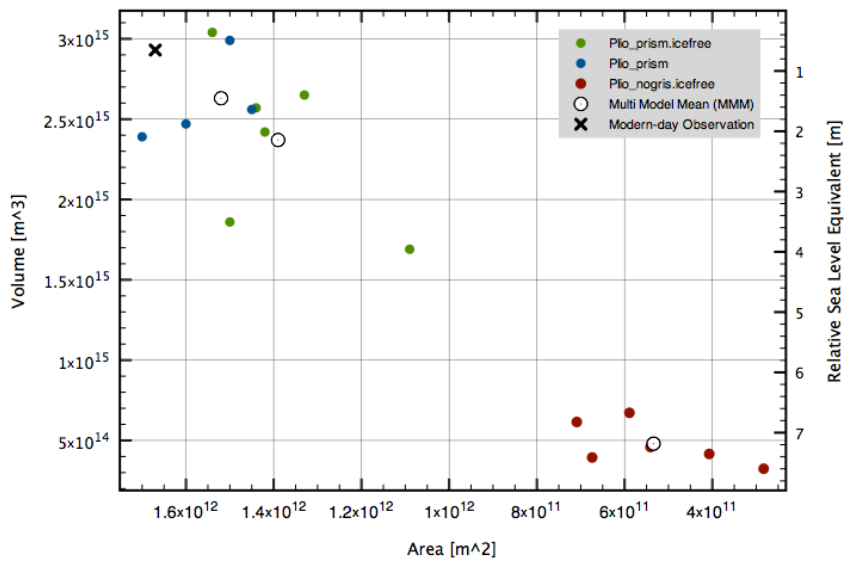

Figure 7. Ice sheet volume $\left[\mathrm{m}^{3}\right]$ and area $\left[\mathrm{m}^{2}\right]$ of Pliocene scenarios Plio $_{\text {prism.icefree (green), Plio prism (blue), and Plio }}$ nogris.icefree (red) with relative sea level equivalent $[\mathrm{m}]$ with respect to present-day reconstructions. Cross denotes volume and area for Bamber et al. (2001a), open circles indicate multi-model means (MMM) for the respective scenarios.

Csank et al., 2011). We conclude that ice presence was most likely limited to the eastern and southern high altitudes resembling scenario Plio $_{\text {nogris.icefree, }}$ as simulated with highest confidence (Fig. 6), and in agreement with proxies.

Equilibrated ice sheet volumes and extents are a result and combination of initial ice sheet model configurations (boundary conditions), ice sheet default parameters and physical constants (Ritz et al., 1996; Rutt et al., 2009), and forcing climatologies. Model results show that Pliocene scenarios forced with the same GCM climatology are comparable, independent of the ice sheet model used. In turn, the Pliocene GCM forcing with altered boundary conditions on Greenland lead to significantly different and relatively smaller ice sheets. Thus, starting ice sheet model configurations on Greenland are found to be of secondary importance in contrast to the uncertainties introduced by a change in the (ice sheet) boundary conditions in the GCM. Although internal ISM-specific parameters have been shown to be critical in ice sheet simulations under similar forcing conditions (see Stone et al., 2010 for an overview), by using state-of-the-art ISMs run in their standard mode, our results point to less ice sheet model dependent results. The ISMs respond very similarly to a certain forcing over large areas of Greenland (see Sect. 3.3.2). As a result, alterations in the GCM boundary conditions have the potential to produce the greatest uncertainty in Pliocene ice sheet modeling.

The results presented here are of importance not just regarding ISM dependency, but they also provide a potential alternative to the PRISM3 ice sheet reconstructions when moving forward with PlioMIP Phase 2. Figure 7 displays ice sheet volumes derived from creating a multi-model mean (MMM) for each Pliocene scenario. It is possible that a MMM reconstruction across all the scenarios presented here 
would be more appropriate for future iterations of PlioMIP than simply relying on one ISM, however there will be difficulties in creating a spatially consistent MMM GrIS. Although the creation of a MMM may be fruitful, it is considered premature at present given the results presented here, which suggest that climatological forcing is more important than ISM dependency. It therefore follows that the climate model used to provide the climatological forcing could have a large impact on the simulated ice sheets. Dolan et al. (2015) are currently assessing the degree to which climate model dependency affects Pliocene ice sheet simulations and provides a useful companion to this paper.

\section{Conclusions}

PLISMIP was initiated in order to address the degree to which ice sheet reconstructions for the Pliocene are dependent on the choice of ISM (Dolan et al., 2012). We show that the degree of ISM dependency is relatively low and in fact the climatological forcing or the boundary conditions applied in the original climate model simulation are of higher importance in terms of the predicted Pliocene ice sheet. We also present the most likely locations of Pliocene ice on Greenland by means of intercomparing model results from six ISMs and forcing conditions. We find that less ice sheet model dependent results require forcings from various GCM scenarios with the same boundary conditions (Haywood et al., 2010, 2011b) to further constrain uncertainties in simulating ice on Pliocene Greenland. Moreover, given Greenland's sensitivity to imposed forcing, we are in need of proxies on and in the proximity of Greenland to (i) help better constrain model starting conditions and (ii) improve the verification of ice sheet model results.

Acknowledgements. S. J. Koenig and R. M. DeConto were supported by the US National Science Foundation under the awards ATM-0513402, AGS-1203910, and OCE-1202632. A. M. Dolan acknowledges financial support from the European Research Council under the European Union's Seventh Framework Programme (FP7/2007-2013)/ERC grant agreement no. 278636 and the Natural Environment Research Council for the provision of a Doctoral Training Grant. D. J. Hill acknowledges the Leverhulme Trust for the award of an Early Career Fellowship and the National Centre for Atmospheric Science and the British Geological Survey for financial support. E. J. Stone is supported by the NERC consortium iGlass NE/I010874/1. B. de Boer would like to thank Thomas Reerink for support and development of the ANICE model. The authors also acknowledge Jochen Voss for some helpful discussions on the manuscript.

Edited by: A. Dutton

\section{References}

Alley, R. B., Clark, P. U., Huybrechts, P., and Joughin, I.: Ice-sheet and sea-level changes, Science, 310, 456-60, 2005.

Alley, R., Andrews, J., and Brigham-Grette, J.: History of the Greenland Ice Sheet: paleoclimatic insights, Quaternary Sci. Rev., 29, 1728-1756, 2010.

Bamber, J. and Aspinall, W. P.: An expert judgement assessment of future sea level rise from the ice sheets, Nat. Clim. Change, 3, 424-427, 2013.

Bamber, J., Ekholm, S., and Krabill, W.: A new, high-resolution digital elevation model of Greenland fully validated with airborne laser altimeter data, J. Geophys. Res., 106, 6733-6745, 2001a.

Bamber, J., Layberry, R., and Gogineni, S.: A new ice thickness and bed data set for the Greenland ice sheet. 1- Measurement, data reduction, and errors, J. Geophys. Res.-Atmos., 106-33, $2001 \mathrm{~b}$.

Berger, A.: An exceptionally long interglacial ahead?, Science, 297, 1287-1288, 2002.

Bhattacharya, I., Jezek, K. C., Wang, L., and Liu, H.: Surface melt area variability of the Greenland ice sheet: 1979-2008, Geophys. Res. Lett., 36, 1-6, 2009.

Bindoff, N., Willebrand, J., Artale, V., Cazenave, A., Gregory, J., Gulev, S., and Hanawa, K.: Observations: oceanic climate change and sea level., in: IPCC, AR4, Cambridge University Press, 337383, 2007.

Box, J.: Survey of Greenland instrumental temperature records: 1873 - 2001, Intern. J. Climat., 22, 1829-1847, 2001.

Box, J., Bromwich D.H., and Bai L.S.: Greenland ice sheet surface mass balance 1991-2000: Application of Polar MM5 mesoscale model and in situ data, J. Geophys. Res., 109, 1-21, 2004.

Calov, R. and Ganopolski, A.: Multistability and hysteresis in the climate-cryosphere system under orbital forcing, Geophys. Res. Lett., 32, L21717, doi:10.1029/2005GL024518, 2005.

Colville, E. J., Carlson, A. E., Beard, B. L., Hatfield, R. G., Stoner, J. S., Reyes, A. V., and Ullman, D. J.: Sr-Nd-Pb isotope evidence for ice-sheet presence on southern Greenland during the Last Interglacial, Science, 333, 620-623, 2011.

Crowley, T. J. and Baum, S. K.: Is the Greenland Ice Sheet Bistable?, Paleoceanography, 10, 357-363, 1995.

Csank, A., Patterson, W., Eglington, B., Rybczynski, N., and Basinger, J.: Climate variability in the Early Pliocene Arctic: Annually resolved evidence from stable isotope values of sub-fossil wood, Ellesmere Island, Canada, Palaeogeography, Palaeoclimatology, Palaeoecology, 308, 339-349, 2011.

Cuffey, K. M. and Marshall, S. J.: Substantial contribution to sealevel rise during the last interglacial from the Greenland ice sheet, Nature 404, 591-594, 2000.

de Boer, B. Wal, R. S. W., Lourens, L. J., Bintanja, R., and Reerink, T. J.: A continuous simulation of global ice volume over the past 1 million years with 3-D ice-sheet models, Clim. Dynam., 41, 1365-1384, 2013.

Dolan, A. M., Haywood, A. M., Hill, D. J., Dowsett, H. J., Hunter, S. J., Lunt, D. J., and Pickering, S. J.: Sensitivity of Pliocene ice sheets to orbital forcing, Palaeogeography, Palaeoclimatology, Palaeoecology, 309, 98-110, 2011.

Dolan, A. M., Koenig, S. J., Hill, D. J., Haywood, A. M., and DeConto, R. M.: Pliocene Ice Sheet Modelling Intercomparison Project (PLISMIP) - experimental design, Geosci. Model Dev., 5, 963-974, doi:10.5194/gmd-5-963-2012, 2012. 
Dolan, A. M., Hunter, S. J., Hill, D. J., Haywood, A. M., Koenig, S. J., Otto-Bliesner, B. L., Abe-Ouchi, A., Bragg, F., Chan, W-L., Chandler, M. A., Contoux, C., Jost, A., Kamae, Y., Lohmann, G., Lunt, D. J., Ramstein, G., Rosenbloom, N. A., Sohl, L., Stepanek, C., Ueda., H, Yan, Q., and Zhang, Z.: On the Climate Model Dependency of Simulations of the Greenland Ice Sheet during the Mid-Pliocene Warm Period, Climate of the Past, under review, 2015.

Dowsett, H., Robinson, M., Haywood, A., Salzmann, U., Hill, D., Sohl, L., Chandler, M., Williams, M., Foley, K., and Stoll, D.: The PRISM3D paleoenvironmental reconstruction, Stratigraphy, 7, 123-139, 2010a.

Dowsett, H. J., Robinson, M. M., Stoll, D. K., and Foley, K. M.: Mid-Piacenzian mean annual sea surface temperature: an analysis for data-model comparisons, Stratigraphy, 7, 189-198, $2010 \mathrm{~b}$.

Dowsett, H. J., Robinson, M. M., Haywood, A. M., Hill, D. J., Dolan, A. M., Stoll, D. K., Chan, W. L., Abe-Ouchi, A,. Chandler, M. A., and Rosenbloom, N. A.: Assessing confidence in Pliocene sea surface temperatures to evaluate predictive models, Nat. Clim. Change, 2, 365-371, 2012.

Fyke, J. G., Weaver, A. J., Pollard, D., Eby, M., Carter, L., and Mackintosh, A.: A new coupled ice sheet/climate model: description and sensitivity to model physics under Eemian, Last Glacial Maximum, late Holocene and modern climate conditions, Geosci. Model Dev., 4, 117-136, doi:10.5194/gmd-4-1172011, 2011.

Gregory, J. M., Huybrechts, P., and Raper, S. C. B.: Climatology: Threatened loss of the Greenland ice-sheet, Nature, 428, 2513, 2004.

Greve, R.: On the response of the Greenland ice sheet to greenhouse climate change, Clim. Change, 46, 289-303, 2000.

Haywood, A. M., Dowsett, H. J., Otto-Bliesner, B., Chandler, M. A., Dolan, A. M., Hill, D. J., Lunt, D. J., Robinson, M. M., Rosenbloom, N., Salzmann, U., and Sohl, L. E.: Pliocene Model Intercomparison Project (PlioMIP): experimental design and boundary conditions (Experiment 1), Geosci. Model Dev., 3, 227-242, doi:10.5194/gmd-3-227-2010, 2010.

Haywood, A. M., Ridgwell, A., Lunt, D., Hill, D., Pound, M., Dowsett, H., Dolan, A.M., Francis, J., and Williams, M.: Are there pre-Quaternary geological analogues for a future greenhouse warming?, Phil. Trans. Roy. Soc. A, 369, 933, 2011.

Haywood, A. M., Dowsett, H. J., Robinson, M. M., Stoll, D. K., Dolan, A. M., Lunt, D. J., Otto-Bliesner, B., and Chandler, M. A.: Pliocene Model Intercomparison Project (PlioMIP): experimental design and boundary conditions (Experiment 2), Geosci. Model Dev., 4, 571-577, doi:10.5194/gmd-4-571-2011, 2011.

Helsen, M. M., van de Berg, W. J., van de Wal, R. S. W., van den Broeke, M. R., and Oerlemans, J.: Coupled regional climate-icesheet simulation shows limited Greenland ice loss during the Eemian, Clim. Past, 9, 1773-1788, doi:10.5194/cp-9-1773-2013, 2013.

Hill, D. J.:Modelling Earth's Cryosphere during peak Pliocene warmth, Ph.D. thesis, University of Bristol, 368 pp., 2009.

Hindmarsh, R.: Modelling the dynamics of ice sheets, Progress in Physical Geography, 17, 391, 1993.

Huybrechts, P. and de Wolde, J.: The dynamic response of the Greenland and Antarctic ice sheets to multiple-century climatic warming, J. Clim., 12, 2169-2188, 1999.
Huybrechts, P., Goelzer, H., Janssens, I., Driesschaert, E., Fichefet, T., Goosse, H., and Loutre, M. F.: Response of the Greenland and Antarctic Ice Sheets to multi-millennial greenhouse warming in the earth system model of intermediate complexity LOVECLIM, Surveys in Geophysics, 1-20, 2011a.

Huybrechts, P., Goelzer, H., Janssens, I., Driesschaert, E., Fichefet, T., Goosse, H., and Loutre, M. F.: Response of the Greenland and Antarctic Ice Sheets to Multi-Millennial Greenhouse Warming in the Earth System Model of Intermediate Complexity LOVECLIM, Surveys in Geophysics, 32, 397-416, 2011 b.

Jansen, E., Fronval, T., Rack, F., and Channell, J. E. T.: PliocenePleistocene ice rafting history and cyclicity in the Nordic Seas during the last 3.5 Myr, Paleoceanography, 15, 709-721, 2000.

John, K., and Krissek, L.: The late Miocene to Pleistocene icerafting history of southeast Greenland, Boreas, 31, 28-35, 2002.

Kanamitsu, M., Ebisuzaki, W., Woollen, J., Yang, S., Hnilo, J., Fiorino, M., and Potter, G.: NCEP-DOE AMIP-II re-analysis (R-2), B. Am.n Meteorol. Soc. 83, 1631-1644, 2002.

Kleiven, H., Jansen, E., Fronval, T., and Smith, T.: Intensification of Northern Hemisphere glaciations in the circum Atlantic region (3.5-2.4 Ma)-ice-rafted detritus evidence, Palaeogeography, Palaeoclimatology, Palaeoecology, 184, 213-223, 2002.

Koenig, S. J., DeConto, R. M., and Pollard, D.: Late Pliocene to Pleistocene sensitivity of the Greenland Ice Sheet in response to external forcing and internal feedbacks, Clim. Dyn., 37, 12471268, 2011.

Koenig, S. J., DeConto R. M., and Pollard, D.: Impact of reduced Arctic sea ice on Greenland ice sheet variability in a warmer than present climate, Geophys. Res. Lett., 41, 3933-3942, 2014.

Larsen, H. C., Saunders, A. D., Clift, P. D., Beget, J., Wei, W., and Spezzaferri S.: Seven million years of glaciation in Greenland., Science, 264, 952-5, 1994.

Lawrence, K. T., Herbert, T. D., Brown, C. M., Raymo, M. E., and Haywood, A. M.: High amplitude variations in North Atlantic sea surface temperature during the Early Pliocene Warm Period, Paleoceanography, 24, 2218, 2009.

Lemke, P., Ren, J., Alley, R. B., Allison, I., Carrasco, J., Flato, G., Fujii, Y., Kaser, G., Mote, P., Thomas, R. H., and Zhang, T.: Observations: Changes in snow, ice and frozen ground., Climate Change 2007: The Physical Science Basis, Contribution of Working Group I to the Fourth Assessment Report of the Intergovernmental Panel on Climate Change, edited by: Solomon, S., Qin, D., Manning, M., Chen, Z., Marquis, M., Averyt, K. B., Tignor, M., and Miller, H. L., Cambridge University Press, Cambridge, United Kingdom and New York, NY, USA, AR4, 337383, 2007.

Lisiecki, L. E. and Raymo, M. E.: A Pliocene-Pleistocene stack of 57 globally distributed benthic $\delta 18$ O records, Paleoceanography, 20, 1-17, 2005.

Loutre, M. F.: Greenland ice sheet over the next 5000 years, Geophys. Res. Lett., 22, 783-786, 1995.

Lunt, D. J., de Noblet-Ducoudré, N., and Charbit, S.: Effects of a melted Greenland Ice Sheet on climate, vegetation, and the cryosphere, Clim. Dyn., 23, 679-694, 2004.

Lunt, D. J., Foster, G. L., Haywood, A. M., and Stone, E.J.: Late Pliocene Greenland glaciation controlled by a decline in atmospheric $\mathrm{CO}_{2}$ levels, Nature, 454, 1102-1105, 2008. 
Lunt, D. J., Haywood, A. M., Foster, G. L., and Stone, E. J.: The Arctic cryosphere in the Mid-Pliocene and the future, Philosophical Transactions of the Royal Society A, 367, 49, 2009.

Mernild, S., Thomas, L., and Liston, G.: Greenland ice sheet surface melt extent and trends: 1960-2010, J. Glaciol., 57, 621, 2011.

Mote, T.: Greenland surface melt trends 1973-2007: Evidence of a large increase in 2007, Geophys. Res. Lett., 34, L22, 507, 2007.

Nielsen, T. and Kuijpers, A.: Only 5 southern Greenland shelf edge glaciations since the early Pliocene, Nature, 1875, Scientific Reports: 3, Article number: 1875, 1991.

NEEM Community Members: Eemian interglacial reconstructed from a Greenland folded ice core, Nature, 439, 489-494, 2013.

Ohmura, A.: New precipitation and accumulation maps for Greenland, J. Glaciol., 37, 140-148, 1991.

Ohmura, A., Calanca, P., Wild, M., and Anklin, M.: Precipitation, accumulation and mass balance of the Greenland ice sheet. With 5 figures, Zeitschrift fur Gletscherkunde und Glazialgeologie, 35 , 1-20, 1999.

Otto-Bliesner, B. L., Marshall, S. J., Overpeck, J. T., Miller, G. H., and $\mathrm{Hu}, \mathrm{A} .:$ Simulating Arctic climate warmth and icefield retreat in the Last Interglaciation, Science, 311, 1751-1753, 2006.

Pagani, M., Liu, Z., LaRiviere, J., and Ravelo, A. C. High Earthsystem climate sensitivity determined from Pliocene carbon dioxide concentrations, Nat. Geosci., 3, 27-30, 2009.

Peyaud, V., Ritz, C., and Krinner, G.: Modelling the Early Weichselian Eurasian Ice Sheets: role of ice shelves and influence of ice-dammed lakes, Clim. Past, 3, 375-386, doi:10.5194/cp-3375-2007, 2007.

Pollard, D.: A retrospective look at coupled ice sheet-climate modeling, Clim. Change, 100, 173-194, 2010.

Pollard, D. and DeConto, R. M.: Hysteresis in Cenozoic Antarctic ice-sheet variations, Glob. Planet. Change, 45, 9-21, 2005.

Pollard, D. and DeConto R. M.: A coupled ice-sheet/iceshelf/sediment model applied to a marine margin flowline: Forced and unforced variations, Special Publication - International Association of Sedimentologists, 39, 2007.

Pollard, D. and DeConto, R. M.: Description of a hybrid ice sheetshelf model, and application to Antarctica, Geosci. Model Dev., 5, 1273-1295, doi:10.5194/gmd-5-1273-2012, 2012.

Raymo, M. and Mitrovica, J.: Collapse of polar ice sheets during the stage 11 interglacial, Nature, 483, 453-456, 2012.

Raymo, M., Mitrovica, J., O’Leary, M., DeConto, R., and Hearty P.: Departures from eustasy in Pliocene sea-level records, Nat. Geosci., 4, 328-332, 2011.

Reyes, A. V., Carlson, A. E., Beard, B. L., Hatfield, R. G., Stoner, J. S., Winsor, K., Welke, B., and Ullman, D. J.: South Greenland ice-sheet collapse during Marine Isotope Stage 11, Nature, 510, 525-528, 2014.

Ridley, J., Huybrechts, P., and Gregory, J.: Elimination of the Greenland ice sheet in a high $\mathrm{CO}_{2}$ climate, J. Climate, 18, 3409-3427, 2005.

Ridley, J., Gregory, J. M., Huybrechts, P., and Lowe, J.: Thresholds for irreversible decline of the Greenland ice sheet, Clim. Dyn., 35, 1065-1073, 2010.

Rignot, E., Box, J., Burgess, E., and Hanna, E.: Mass balance of the Greenland ice sheet from 1958 to 2007, Geophys. Res. Lett., 35, doi:10.1029/2008g1035417, 2008.

Rignot, E., Velicogna, I., van den Broeke, M. R., Monaghan, A., and Lenaerts, J.: Acceleration of the contribution of the Greenland and Antarctic ice sheets to sea level rise, Geo. Res. Lett., 38, 15, 2011.

Ritz, C., Fabre, A., and Letréguilly, A.: Sensitivity of a Greenland ice sheet model to ice flow and ablation parameters: consequences for the evolution through the last climatic cycle, Clim. Dyn., 13, 11-23, 1996.

Ritz, C. and Rommelaere, V.: Modeling the evolution of Antarctic ice sheet over the last 420,000 years: Implications for altitude changes in the Vostok region, J. Geophys. Res., 106, 31943 31964, 2001.

Robinson, A., Fabre, R., Calov, R., and Ganopolski, A.: Multistability and critical thresholds of the Greenland ice sheet, Nat. Clim. Change, 2, 429-432, 2012.

Rutt, I., Hagdorn, M., Hulton, N., and Payne, A.: The Glimmer community ice sheet model, J. Geophys. Res., 114, 1-22, 2009.

Saito, F.: Development of a three dimensional ice sheet model for numerical studies of Antarctic and Greenland ice sheet, Tokyo, University of Tokyo, Center for Climate System Research, CCSR Report 15, 2002.

Saito, F. and Abe-Ouchi, A.: Thermal structure of Dome Fuji and east Dronning Maud Land, Antarctica, simulated by a threedimensional ice-sheet model, Ann. Glaciol., 39, 433-438 , 2004.

De Schepper, S., Gibbard, P. L., Salzmann, U., and Ehlers, J.: A global synthesis of the marine and terrestrial evidence for glaciation during the Pliocene Epoch, Earth Sci. Revi., 135, 83-102, 2014.

Seki, O., Foster, G. L., Schmidt, D. N., Mackensen, A., Kawamura, K., and Pancost, R. D.: Alkenone and boron-based Pliocene $\mathrm{CO}_{2}$ records, Earth Planet. Sci. Lett., 292, 201-211, 2010.

Shepherd, A., Ivins, E. R., Geruo, A., Barletta, V. R., Bentley, M. J., Bettadpur, S., Briggs, K. H., Bromwich, D. H., Forsberg, R., Galin, N., Dowsett, H.J., Robinson, M. M., Haywood A. M., Hill, D.J., Dolan, A. M., Stoll, D. K., Chan, W. L., Abe-Ouchi, A., Chandler, M. A., Rosenbloom, N. A., Miller, K. G., Wright, J. D., Browning, J. V., Kulpecz, A., Kominz, M., Naish, T. R., Cramer, B. S., Rosenthal, Y., Peltier, W. R., and Sosdian, S.: A reconciled estimate of ice-sheet mass balance, Nat. Clim. Change, 338, 365371, 2012.

Siddall, M., Abe-Ouchi, A., Andersen, M., Antonioli, F., Bamber, J., Bard, E., Clark, J., Clark, P., Deschamps, P., and Dutton, A.: The sea-level conundrum: case studies from palaeo-archives, J. Quat., Science, 25, 19-25, 2010.

Solgaard, A. M., Reeh, N, Japsen, P., and Nielsen, T.: Snapshots of the Greenland ice sheet configuration in the Pliocene to early Pleistocene, J. Glaciol., 57, 871-880, 2011.

Stone, E. J. and Lunt, D. J.: The role of vegetation feedbacks on Greenland glaciation, Clim. Dyn., 40, 2671-2686, 2013.

Stone, E. J., Lunt, D. J., Rutt, I. C., and Hanna, E.: Investigating the sensitivity of numerical model simulations of the modern state of the Greenland ice-sheet and its future response to climate change, The Cryosphere, 4, 397-417, doi:10.5194/tc-4-397-2010, 2010.

Thompson, S. L. and Pollard, D.: Greenland and Antarctic mass balances for present and doubled atmospheric $\mathrm{CO}_{2}$ from the GENESIS version-2 global climate model, J. Climate, 10, 871-900, 1997.

Toniazzo, T., Gregory, J. M., and Huybrechts, P.: Climatic impact of a Greenland deglaciation and its possible irreversibility, J. Climate, 17, 21-33, 2004. 
van de Berg, W., van den Broeke, M., Ettema, J., van Meijgaard, E., and Kaspar, F.: Significant contribution of insolation to Eemian melting of the Greenland ice sheet, Nat. Geosci., 4, 679-683, 2011.

van den Broeke, M., Bamber, J., Ettema, J., Rignot, E., Schrama, E., van de Berg, W. J., van Meijgaard, E., Velicogna, I., and Wouters, B.: Partitioning recent Greenland mass loss, Science, 326, 984 986, 2009.

Vizcaíno, M., Mikolajewicz, U., Gröger, M., Maier-Reimer, E., Schurgers, G., and Winguth, A. M. E.: Long-term ice sheetclimate interactions under anthropogenic greenhouse forcing simulated with a complex Earth System Model, Clim. Dyn., 31, 665-690, 2008.
Weng, W.: Untitled, Arctic, 48, 206-206, 1995.

Wolf-Welling, T., Cremer, M., O'Connell, S., Winkler, A., and Thiede, J.: Cenozoic Arctic gateway paleoclimate variability: Indications from changes in coarse-fraction composition, In: Proceedings of the Ocean Drilling Program, Scientific results, Ocean Drilling Program, 151, 515-567, 1996. 